\title{
The Implementation of Classical Puppet Drama Performance to Improve English Speaking Skill for International Class Program Students
}

\author{
Sari Famularsih \\ IAIN Salatiga, Salatiga, Indonesia
}

\begin{tabular}{|c|c|}
\hline (A) Check for updates open 0 access cc) (1) (2) & DOI : https://doi.org/10.46245/ijorer.v1i2.41 \\
\hline Article Info & ABSTRACT \\
\hline Article history: & This study analyzed the implementation of classical puppet drama \\
\hline Submitted: June 17, 2020 & performance to improve students' speaking skills in the International Class \\
\hline Final Revised: June 25, 2020 & Program of one of the universities in Salatiga. The teaching and learning \\
\hline Accepted: July 11, 2020 & processes in drama class were (1) asking the students with the question, (2) \\
\hline Published Online: July 31, 2020 & designing drama project plan, (3) creating drama preparation schedules, (4) \\
\hline Key & monitoring the students in preparing the drama, (5) assessing the outcome, \\
\hline 4Cs skills & and (6) evaluating students' drama performance. This study was qualitative \\
\hline Drama performance & research in the form of a case study. To collect the data, the researcher used \\
\hline Speaking skill & observation, interview, documentation, and questionnaire. The results \\
\hline 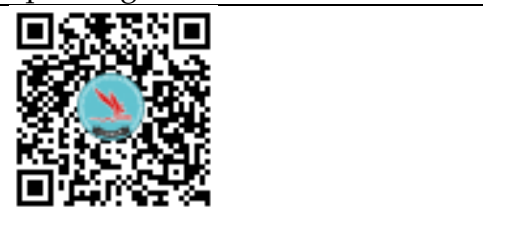 & $\begin{array}{l}\text { showed that by using drama performance, students can improve their } \\
\text { pronunciation, fluency, accuracy, handle the voice, and body language to } \\
\text { improve their self-confidence to speak in English. Moreover, the use of } 4 \mathrm{Cs} \\
\text { skills activities namely critical thinking, communication, collaboration, and } \\
\text { creativity skills in the classroom can stimulate students to improve their } \\
\text { group work and interaction among students. }\end{array}$ \\
\hline
\end{tabular}

\section{INTRODUCTION}

Language is an inseparable aspect of human beings. It is close to Wardhaugh's statement (Wardhaugh, 2006), who said that language is related to what people speak in society. People communicate through language to establish a relationship with others. People need to learn various types of language. People do not need to learn the first language because it has been introduced initially as people start to use language to communicate. However, there are situations in which people learn either a second language or a foreign language. Wilkins in An Encyclopedia of Language argues that the first situation where the individual learns either second or foreign language because that one lives in the environment in which more society used more than one language to communicate which leads to being bilingual users (Collinge, 2002). On the contrary, the second condition of the second or foreign language learning takes place through the tutorial process in which typically is included in the curriculum of the language learner.

In the 21st century, people, especially students, are pushed to be fluent in speaking a foreign language. It is not just to follow the trend but also to fulfill the demand in the Digital Economy. The partnership of 21st Century Learning or P21 proposes the skills achieved by the students. P21 states that there are 19 skills in 21st-century skills in which the students need to have a knowledge development and understanding about each of them. Furthermore, the 19 skills of 21st-century skills divided into three groups (Partnership of $21^{\text {st }}$ Century Learning, 2015). The first group is learning and innovation that consist of creativity and innovation, critical thinking and problem solving, communication, and collaboration. The second group is information and technology that consist of information literacy, media literacy, and ICT literacy. The last group is life and career that consist of flexibility and adaptability, initiative and self-direction, and social 
and cross-cultural skills, productivity and accountability, and leadership and responsibility.

From the three groups of skills, there are four fundamental skills which the students have to achieve. Those are creativity, critical thinking, communication, and collaboration, or 4 Cs skills. Moreover, Wallwork offers an opinion that he agrees to flatter 4 Cs skills as a soft skill key for students to be competitive and competent in finding jobs by emphasizing creativity, critical thinking, communication, and collaboration skills (Wallwork, 2015). Indeed, students who will graduate from the school or university and intend to achieve the best career in the future need to master those skills. Trilling and Fadel (2012) copied from Partnership for 21st-century learning (P21) state that the keys in students' lifetime of learning and creative work are critical thinking and problem solving, communication, collaboration, creativity, and innovation (Trilling \& Fadel, 2012). Therefore, to achieve 4Cs skills, students should master the criteria for each skill described further.

In the 21st century, creativity and innovation are important to develop a knowledge society (Ferrari et al., 2009). Piirto identifies most people think that creativity is about visual arts and the other arts (Piirto, 2011). However, she points out that creativity is all about creating something new in all areas. Beghetto says that creativity will be used by students in designing the project in the classroom and identify this skill, the teacher can assess the students from their talent, arts, and personal characteristics (Beghetto, 2005). Moreover, Gambrill \& Gibbs (2009) argue (that creativity plays a role in critical thinking because it may be required to discover assumptions, alternative explanations, and biases. The criteria of creativity skill are mentioned by Trilling \& Fadel (2012) namely think creatively, work creatively with others, and implement innovations. Therefore, students should have these criteria to gain creativity skills.

The second skill of 4 Cs skills is critical thinking. Critical thinking is self-guided and self-disciplined thinking (Critical Thinking Community, 2015). This community also argues that people who think critically and consistently attempt to live rationally, reasonably, empathically. Brookfield analyses the people who cannot think critically at the list; they will have three problems (Brookfield, 2012). First, they will have some risks in their life without being aware of it. Second, they will have no opportunity to recognize something when they manipulated. Third, they will have a limited chance of obtaining what they want. Brookfield emphasizes that critical thinking is not only an academic purpose but also as a way of life. Critical thinking consists of seeing both sides of an issue, being open to new evidence that disconfirms the ideas, reasoning dispassionately, demanding that claims be backed by evidence, deducing and inferring conclusions from available facts, solving problems, and so on (Willingham, 2007).

The third skill, communication is the process of transmitting information and common understanding from speaker to listener (Keyton, 2011). Yate states the most important aspect for an ideal candidate in finding a job is communication skill (Yate, 2009). The last skill is collaborative skill. Lai suggests that collaboration defined as a mutual engagement of participants in a coordinated effort to solve a problem together (Lai, 2011). He also argues that collaborative interactions consist of shared goals, symmetry of the structure, and a high degree of negotiation, interactivity, and interdependence. Elaboration in interaction is important in improving students learning. This skill is particularly valuable for students who have low achievement.

The implications of the 4Cs skills for the 21st Century are it articulates the 4Cs skills, it explains the "Rainbow" framework of the full set of essential 21st-century skills as 
conceptualized by The Partnership for 21st Century Skills, and it outlines Bruner's 5E Instructional Model and explains how it provides an excellent lens through which to approach learning, teaching, assessment, and curriculum development for the 4Cs skills (Kivunja, 2015).

In implementing drama in teaching and learning processes is not a new issue and not only conduct in elementary school but for university students as well. Drama performance could probably be used in any or all levels of the lesson (Saygili, 2015). The implementation of drama activity in language learning gives advantages both for students and lecturers. Drama as one of the most effective learning activities to help students to learn and the teacher's design learning situations for their students (Ranzau, 2016). Native language teaching courses that utilize creative drama activities are more efficient in developing oral communication skills in primary school students than the traditionally applied native language teaching courses. The data conducted through pretest and post-test.

There are seven reasons why using drama in the language classroom is a powerful learning media namely (1) To foster students to communicate for real purposes, (2) To make an active motivating experience in the language classroom (3) To help students improve their confidence and self-esteem needed to speak spontaneously, (4) To bring the students into the real world in the classroom, (5) To make the memorable experience in language learning memorable thorough direct learning, (6) To stimulate the students' imagination, and creativity, (7) To develop students' communication skill (Alvarado, 2017). To sum up, conducting drama in language learning activity especially in speaking skills can improve students' soft skills and hard skills. Moreover, the use of drama activities in speaking provides more opportunities for students to practice and build interaction and collaboration skills with their friends.

Art and language are a means for university students to express their feelings and thoughts in beautiful and extraordinary ways. Art becomes a means of expressing feelings and thoughts in a non-verbal way while the language used for human verbal concepts. Indeed, the communication between human being becomes effective and informative. In teaching and learning processes, the drama was performed by International Class Program (ICP) students in the Art and Language Exhibition (ALE). It is arranged by International Class Program (ICP) students which is the collaboration of three majors; English Department Students, Arabic Department Students, and Islamic Education Department Students in performing art-works through the exhibition, which touted the bilingual use of English and Arabic. However, the researcher affirms that this study only focusses on students' English mastering, especially in mastering the speaking skill through the classical puppet drama performance. Moreover, the title of the students' drama performance was "Sumpah Asmara Abimanyu". Indeed, the researcher is interested in conducting the study focuses on teaching drama class by using 4 Cs skills activities in the classroom to improve the students' speaking skills.

\section{Research Questions}

Based on the background of the study, the researcher formulates some problems of the study as follows:

1. How is the teaching and learning process by using $4 \mathrm{C}$ skills activities in drama class to improve students' speaking skill?

2. How is the students' speaking skill after performing classical puppet drama? 


\section{RESEARCH METHOD}

\section{General Background}

This study is a descriptive qualitative in the form of a case study. Further, the data of this study was useful to get a better understanding of how the lecturer implement the teaching and learning process by using $4 \mathrm{C}$ skills activities in drama class to improve students' speaking skill. According to Cohen, Manion, and Morrison (2000), that case study strives to portray 'what is like' to be in a particular situation, to catch the close-up really and thick description of participants lived experiences of thoughts, feeling, and situation. The data of this research gained from the interview to the lecturer and questionnaire answered by the students.

\section{Participants}

The subject of this research is the 4th-semester students of the International Class Program in the Academic Year of 2017/2018. The total of the subjects is a drama class lecturer and 20 students. They are seven students from Islamic Education Department, five students from the Arabic Education Department, and eight students from the English Education Department.

\section{Instrument and Procedures}

The instrument to collect the data, the researcher used interview, observation, questionnaire, and documentation. The researcher used the theory from Moleong to analyze the data, i.e. identification, coding, classifying, and producing an account (Moleong, 2009).

\section{Data Analysis}

To analyze the data, the researcher used methodological triangulation due to the use of more than one method to collect the data.

\section{RESULTS AND DISCUSSION}

This part discussed research findings in correlation with the implementation of classical puppet drama performance to improve English speaking skills for International Class Program students. The findings are categorized into two categories namely (1) How is the teaching and learning process by using $4 \mathrm{C}$ skills activities in drama class to improve students' speaking skills? and (2) How is the result of the students' speaking skills after performing classical puppet drama?

\section{How is the teaching and learning processes by using 4 Cs skills activities in drama class} to improve students' speaking skill?

In the teaching and learning process in the classroom, based on the observation the lecturer taught the students by using this six steps namely (1) asking the students with the question, (2) designing drama project plan, (3) creating drama preparation schedules, (4) monitoring the students in preparing the drama, (5) assessing the outcome, and (6) evaluating students' drama performance.

Related to teaching and learning processes in drama class using 4Cs skills activities namely critical thinking, communication, collaboration, and creativity skills are explained below. Critical thinking skills can be found in some activities in this drama class. First, when the lecturer asked his students some questions related to drama preparation. He stimulates his students by giving some questions after watching 
YouTube videos about drama performance and asked his students to analyze the video and answer their lecturer's questions individually and group. Second, in designing a drama script, the lecturer asked his students to think critically in arranging the drama script by choosing the scene, character, and plot. In selecting the characters, the lecturer examined the students by casting in front of their friends. As a result, the students could criticize their friends' performance and discussed about the suitable characters based on drama script. In these activities, the students tried to solve the problem together in arranging the drama (Willingham, 2007). The students also can learn to give the reason logically to not be manipulated with other arguments (Brookfield, 2012).

Furthermore, communication and collaboration skills can be found in some activities especially when the students discussed together in preparing the drama. They have interactions between student and student or lecturer and student in the classroom (Keyton, 2011). The students' discussion was conducted in a group; therefore, each student has his or her responsibility, this activity contains collaboration skills which all students help each other to accomplish their drama project (Lai, 2011). As mentioned before the institution supports the students' project by giving them opportunities to learn acting with the expert of acting. It also helped the students in improving their collaboration skills in real-life when they collaborate with many people. Moreover, they should practice regularly and continually, in the aims of giving a natural classical puppet drama playing. The foremost, all those steps have a cyclical process; when the practice senses weird, they then revised the script and the act, repeatedly practice, and so on.

From the observation, the drama class provided creativity skill activities. Those activities in the classroom were writing the story, decorating the auditorium, and designing the wardrobe for drama. In designing the drama, the students were asked by their lecturer to make a good drama. Therefore, it drives students' creativity skills to arrange their drama projects to be more interesting, creative, and innovative (Beghetto, 2005).

In this class, the lecturer not only assess students' speaking skills when the students performed their drama but also support the students to improve their speaking skill in pre-production activities in the classroom. The lecturer leads students' discussion using full English to stimulate the students to speak English. The lecturer also gave motivation to the students to speak loud and clear enough that it will attract the herd into their explanation or opinion in a discussion.

\section{How is the students' speaking skill after performing classical puppet drama?}

In the interview session, the researcher asked the lecturer to explain how he assessed the students' speaking skills. The lecturer assessed the students using a rubric with these criteria namely pronunciation, fluency, accuracy, loud and clear voice, and body language. As mentioned before, this International Class Program consists of three major programs namely 8 students of English Education, 5 students of Arabic Education, and 7 students of Islamic Education with different backgrounds of English skills.

The result of the pronunciation assessment was 8 students (Excellent), 9 students (Good), and 3 students (Average). Fluency, 10 students (Excellent), 7 students (Good), and 3 students (Average). Accuracy, 5 students (Excellent), 11 students (Good), and 4 students (Average). Loud and clear voice, 14 (Excellent), 3 students (Good), 1 student (Average), and 2 students (Poor). Body language, 14 students (Excellent), 4 students (Good), 1 student (Average), and 2 students (Poor). It can be concluded that in pronunciation, fluency, accuracy, loud and clear voice are led by English Education 
Program students whereas Islamic Education Program students were the highest score in body language criteria.

As a basic foundation of speaking practice, esp. by performing drama, the students' difficulty solved at first. Based on drawbacks found, the lecturer as facilitator gives students suggestions to cope with those problems. In case of a lack of vocabulary, he asks them to try various techniques to enrich their vocabulary independently. Practice it repeatedly into daily activity. Repetition is also important to train pronunciation and fluency, as well. For grammatical mistakes, the facilitator takes part in fixing inappropriate grammar produced by the students. Sometimes the students used the Indonesian language when they discussed with their group but their lecturer always demanded the students to speak English, so it can improve their speaking and communication skill. The most crucial item to be accustomed is comprehension. When students comprehend the text well, they can improve the acting, the speaking, and the gesture naturally. Thus, it is important to make sure that they will understand the main point of a story. Those all solutions in coping with the basic problem of speaking production then train repeatedly in each preparation process to perform a drama.

The use of 4Cs skills activities were just to stimulus the students to improve their speaking skill therefore they can speak dominantly in the class rather than their lecturer. Based on students' questionnaires about teaching and learning processes in drama class, all students agreed that all the activities in the classroom were to drive the students' English language skills especially speaking skills. Therefore, the lecturer also should explain to the students that between English language skills and 4Cs skills should be balanced (Trilling \& Fadel, 2012). Moreover, the activities in the classroom such as discussion and presentation supported the students' 4Cs skills and language skills especially in speaking (Bender, 2012).

\section{CONCLUSIONS}

Based on the findings and discussions above, the lecturer taught the class by starting with the essential question to improve students' critical thinking skills. The lecturer also participated in designing a plan and creating the schedule of the drama project to improve students' communication and collaboration skills. Moreover, to improve students' creativity skills, the lecturer monitored the students' drama project by giving some feedback to them and it can be seen from their drama performance. This research was conducted to help students in improving speaking skills by maximizing 4Cs skills activities namely critical thinking, communication, collaboration, and creativity skills. The implementation of drama performance will have helped students with each other in solving problems during the learning process or drama preparation. Hence, their involvement and interaction during the learning process were improved. Besides, the use of 4 Cs skills learning activities in drama class also created more speaking opportunities for the students so that they could improve their pronunciation, fluency, accuracy, handle the voice, and body language to improve their self-confidence to speak in English. This technique also created an enjoyable and new atmosphere for students in improving their speaking skills in the classroom. As a result, the process of learning speaking in the classroom became more creative, effective, and interesting. The research will be a new model in teaching practice for teachers and students to implement speaking skills for foreign language learners in studying English. 


\section{ACKNOWLEDGEMENTS}

The author would like to show my gratitude to those who helped in this research, especially funding supporters of my research, proof-readers, typists, editor, and International Class Program Students.

\section{REFERENCES}

Alvarado, J.S. (2017). The use of theatre and drama techniques to foster speaking skills in the English class. Revista de Lenguas Modernas, 26, 305-317.

Beghetto, R.A. (2005). Creativity research and the classroom: From pitfalls to potential. In A.-G. Tan (Ed.), Creativity: A handbook for teachers (pp. 101-114). Singapore: World Scientific.

Bender, W.N. (2012). Project-based learning: Differentiating instruction for the 21st century. Corwin Press.

Brookfield, S., D. (2012). Teaching for critical thinking; tools and techniques to help students question their assumptions. San Francisco: Jossey-Bass.

Cohen, L., Manion, L., \& Morrison, K. (2000). Research methods in education. London: Routledge.

Collinge, N.E. (2002). An encyclopedia of language. London: Routledge.

Critical Thinking Community. (2015). Defining Critical Thinking. Accessed on December 14 2018. Retrieved from: http://www.criticalthinking.org/pages/defining-criticalthinking/766

Ferrari, A., Cachia, R., \& Punie, Y. (2009). Innovation and creativity in education and training in the eu member states: Fostering creative learning and supporting innovative teaching. Literature review on Innovation and Creativity in EET in the EU Member States (ICEAC). Luxembourg: JRC European Communities. Accessed on June 012017 Retrieved from: http://ftp.jrc.es/EURdoc/JRC52374_TN.pdf

Gambrill, E., \& Gibbs, L. (2009). Critical Thinking for helping professionals: A skills-based workbook. Oxford: Oxford University Press.

Germaine, R., Richards, J., Koeller, M., \& Schubert-Irastorza, C. (2016). Purposeful use of 21st century skills in higher education. Journal of Research in Innovative Teaching, 9(1), 19-29.

Keyton, J. (2011). Communication and organizational culture: A key to understanding work experience. Thousand Oaks, CA: SAGE Publication.

Kivunja, C. (2014). Innovative pedagogies in higher education to become effective teachers of 21st-century skills: Unpacking the learning and innovations skills domain of the new learning paradigm. International Journal of Higher Education, 3(4), 37-48.

Lai, E.R. (2011). Collaboration: A literature review. Research Report. Pearson.

Moleong, L.J. (2009). Metodologi penelitian kualitatif. Bandung: Remaja Rosdakarya.

Partnership of $21^{\text {st }}$ Century Learning (P21).(2015). P21 Framework Definitions. Accessed on August $132018 . \quad$ Retrieved from: http://www.p21.org/storage/documents/docs/P21_Framework_Definitions_Ne w_Logo_2015.pdf.

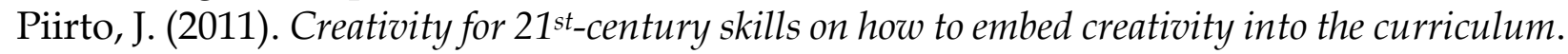
Rotterdam: Sense Publishers.

Ranzau, Sara.J. (2016). Teacher perception of drama pedagogy as a teaching tool. doctor of education (Language, literacy, and special populations), December 2016, Sam Houston University, Huntsville, Texas. 
Saygili, H.K. (2015). Fostering speaking strategies of ESP students via drama: A case study. IGUSBD Cilt. 81-109.

Trilling, B., \& Fadel, C. (2012). 21st-century skills: Learning for life in our times (first). USA: Jossey-Bass. Type of Reasoning. changingmind.org / disciplines /argument/ types.reasoning/types_reasoning.htm (retrieved at September 20th, 2018).

Wallwork, C. (2015). Reframing the 4 Cs: 21st Century Mindsets. Accessed on January 02 2018. Retrieved from: http://eddesignlab.org/2015/03/21st-century-mindsets/

Wardhaugh, R. (2006). An introduction to sociolinguistics. United Kingdom: Blackwell Publishing.

Willingham, T., D. (2007) Critical thinking why is it so hard to teach? American Educator. Accessed on December 14 2016. Retrieved from: http://www.aft.org/sites/default/files/periodicals/Crit_Thinking.pdf

Yate, M. (2009). Hiring the best: A manager's guide to effective interviewing and recruiting. Cincinnati: $\mathrm{OH}$ : F \& W Media.

\footnotetext{
*Sari Famularsih, M.A (Corresponding Author)

English Education Departement, Faculty of Teacher Training and Education, State Institute of Islamic Studies (IAIN) Salatiga, Indonesia.

Jl. Lingkar Salatiga KM 2 Pulutan, Sidorejo, Kota Salatiga, Provinsi Jawa Tengah Indonesia.

Email: $\underline{\text { sarifamularsih@yahoo.com }}$
} 